\title{
Thyroid Carcinoma TNM Finding v8
}

National Cancer Institute

\section{Source}

National Cancer Institute. Thyroid Carcinoma TNM Finding v8. NCI Thesaurus. Code C140896.

A finding about one or more characteristics of thyroid carcinoma, following the rules of the TNM AJCC v8 classification system. 